\title{
Modeling, Simulation, and Analysis of a Reactor System for the Generation of White Liquor of a Pulp and Paper Industry
}

\author{
Ricardo Andreola ${ }^{1,2}$, Regina Maria Matos Jorge ${ }^{1}$, Onélia Aparecida Andreo dos Santos ${ }^{1}$ \\ and Luiz Mario de Matos Jorge ${ }^{{ }^{*}}$ \\ ${ }^{1}$ Universidade Estadual de Maringá; Av. Colombo, 5790; Bloco E46; Sala 9; 87020-900; Maringá - PR - Brasil. \\ ${ }^{2}$ Faculdade Integrado de Campo Mourão; Rodovia BR 158, km 207; Jardim Batel; 87300-970; Campo Mourão - \\ PR - Brasil
}

\begin{abstract}
An industrial system for the production of white liquor of a pulp and paper industry, Klabin Paraná Papéis, formed by ten reactors was modeled, simulated, and analyzed. The developed model considered possible water losses by the evaporation and reaction, in addition to variations in the volumetric flow of lime mud across the reactors due to the composition variations. The model predictions agreed well with the process measurements at the plant and the results showed that the slaking reaction was nearly complete at the third causticizing reactor, while causticizing ends by the seventh reactor. Water loss due to slaking reaction and evaporation occurred more pronouncedly in the slaker reactor than in the final causticizing reactors; nevertheless, the lime mud flow remained nearly constant across the reactors.
\end{abstract}

Key words: Slaker reactor, causticizing reactor, white liquor, mathematical modeling, simulation

\section{INTRODUCTION}

According to the Brazilian Association of Cellulose and Paper (BRACELPA, 2009a), Brazil is one of the largest world producers of cellulose $\left.4^{\text {th }}\right)$ and paper $\left(11^{\text {th }}\right)$. In 2008 , the cellulose and paper industry produced 114,000 direct jobs and 500,000 indirect jobs. In the last ten years (19992008), the production of cellulose paste rose from $7,209,132$ tons to $12,696,546$ tons, while the paper production rose from $6,953,246$ tons to $9,409,450$ tons, with increases of 76.1 and $35.3 \%$, respectively (BRACELPA, 2009b).
This fast growth must continue in the future, mainly due to the high productivity of Brazilian planted forests and the low cost production in relation to other countries (Soares et al., 2007). In addition to this characteristic of the sector in Brazil, the incorporation of new technologies and the application of computational tools tend to consolidate the growth and increase the economic advantages. Among the new technologies, the use of enzymes in pulp bleaching (Medeiros et al., 2007; Vilkari et al., 1994) and the substitution of the conventional causticizing process by the selfcausticizing process are important (Gonçalves et

*Author for correspondence: 1mmj@deq.uem.br 
al., 2008; Zeng and van Heiningen, 2002), which do not require the use of preset slaker reactors as in the conventional process. The use of computational tools to simulate, analyze, optimize, and control processes also already is a reality in the paper sector (Andrade et al., 2009; Lopes et al., 2008; Silva et al., 2008; Malberg and Edwards, 2007; Barber and Scott, 2007; Aguiar and Maciel Filho, 2001; Costa et al., 2004). However, the development of these tools frequently faces the inexistence of appropriate and validated mathematical models.

In Brazil, the company Klabin S.A. produces most of the paper, and the state of Paraná is the second paper and cellulose producer (BRACELPA, $2009 \mathrm{~b}$ ). In the kraft pulping process, the chemical recovery step of causticizing which is utilized to regenerate the hydroxide, the main component of white liquor, has an impact on the operating cost of the kraft mill. A typical causticizing system consists of a slaker and a series or causticizers.

The reactor system of Klabin Paraná Papéis that produces white liquor for the cellulose digesters consists of ten stirred tank reactors: a slaker reactor (SR) that is followed by a series arrangement of nine causticizing reactors, $\mathrm{C} 1$ to C9, as shown in Figure 1. In this system, all the reactors are open at the top, operate at atmospheric pressure, and the last five reactors (C5-C9) are thermally isolated. Green liquor and lime are continually fed into the slaker reactor under stirring. Green liquor from the recovery boiler is basically a diluted $\mathrm{Na}_{2} \mathrm{CO}_{3}$ aqueous solution, while the lime from the calcination kiln is predominantly calcium oxide and inert solids, around $11.5 \%$. Lime immediately reacts with water when it is mixed with the green liquor in the slaker reactor, forming calcium hydroxide through the highly exothermal slaking reaction: $\mathrm{CaO}_{(\mathrm{s})}+\mathrm{H}_{2} \mathrm{O}_{(\mathrm{l})} \rightarrow$ $\mathrm{Ca}(\mathrm{OH})_{2(\mathrm{~s})}$. In turn, calcium hydroxide simultaneously reacts with sodium carbonate in the green liquor to form sodium hydroxide and calcium carbonate through the slightly exothermal reaction: $\mathrm{Na}_{2} \mathrm{CO}_{3(\mathrm{aq})}+\mathrm{Ca}(\mathrm{OH})_{2(\mathrm{~s})} \rightarrow 2 \mathrm{NaOH}_{(\mathrm{aq})}+$ $\mathrm{CaCO}_{3(\mathrm{~s})}$. Two distinct streams leave the reactor outlet: grits and lime mud. The grit stream is constituted of inert solids in lime sedimented at the bottom of the reactor and driven out through the reactor outlet by an inclined endless screw for disposal. The lime mud stream is mostly constituted of unreacted suspended solids and $\mathrm{NaOH}$ and $\mathrm{Na}_{2} \mathrm{CO}_{3}$, in aqueous solution. The suspended solids are formed by the inert substances, such as $\mathrm{CaCO}_{3}$, residual reagents, such as $\mathrm{Ca}(\mathrm{OH})_{2}, \mathrm{CaO}$, and a percent of grits dragged by the lime mud stream. After leaving the slaker reactor, the lime mud stream sequentially runs through the series of nine causticizing reactors (C1-C9) to provide the necessary residence time for the causticizing reaction to complete. The usual residence times $(\tau \mathrm{i}=\mathrm{Vi} / \mathrm{qi})$ are shown in Table 1.

Klabin Paraná Papéis is located in the city of Telêmaco Borba, in Paraná State, south Brazil. It produces paper and cellulose from pine and eucalyptus wood from its own reforestation cultures.

The overall performance of a causticizing system is affected by various factors, such as the quality and quantity of lime, the concentration of the green liquor components, temperature, and mixing intensity (Sethuraman et al.1995). In this sense, the determination of the optimal operating conditions and the possibility of using suitable control systems will contribute to improve the system performance and economy. Both the control and the analysis of the process and the optimization of the operating conditions can be carried out through the development and validation of appropriate mathematical modeling. Uronen and Aurasmaa (1979) developed static and dynamic models for a causticizing plant and lime kiln; however, the level of details given is insufficient. Apparently, it is a black box-type empirical model. It is not possible to prove the use of industrial data in the validation of the models or their applicability. According to the authors, the dynamic models were used with success in a novel control system of both the causticizing plant and the lime kiln.

Table 1 - Usual residence times.

\begin{tabular}{lllllll}
\hline & SR & C1 & C2 & C3,C4 & C5, C6 & C7-C9 \\
\hline$\tau(\mathrm{s})$ & 1051 & 1387 & 1386 & 1385 & 1437 & 1493 \\
\hline
\end{tabular}




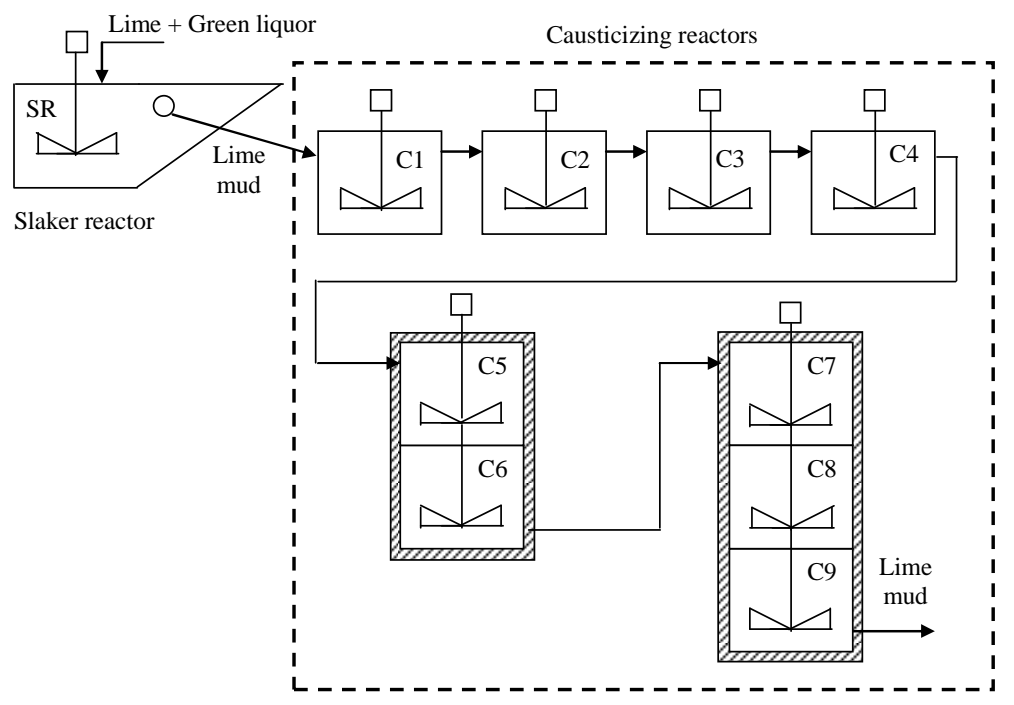

Figure 1 - Klabin Paraná Papéis reactor system.

Andrade et al. (2009) successfully automated an industrial causticizing process by applying an adaptative control system. They overcame the inexistence of a duly identified phenomenological model by using a black box-type transfer function based on a series of Laguerre's orthogonal functions. Swanda et al. (1997) presented one of the few studies in the literature involving the dynamic phenomenological modeling and the validation with industrial data for a conventional causticizing process. The authors developed a phenomenological model based on unsteady-state material and energy balances in the slaker and causticizing reactors and by admitting constant volume, perfect mixture, and apparent concentrations. In this model, the causticizing reaction speed was obtained by adding a $\mathrm{Ca}(\mathrm{OH})_{2}$ concentration term to the empirical kinetics equation of Holman et al. (1991) to account for the influence of the added amount of lime, while the slaking reaction rate was approximated by a firstorder reaction rate expression.

Andreola et al. (2007) analyzed the effect of water loss by evaporation and chemical reaction in an industrial slaker reactor operating in steady state. They developed a dynamic model using an approach similar to that used by Swanda et al. (1997). Among the main differences are the use of actual concentrations instead of apparent concentrations by subtracting the volume of solids in suspension in the calculation of the concentrations and the estimate of the global coefficient value from a $\mathrm{U}$ phenomenological model based on the association of thermal resistances. The predictions of this model in steady state satisfactorily represented the experimental temperature measures, active alkali (AA) and total titrable alkali (TTA), without parameter fitting.

In this context, this work sought to model, simulate, and analyze the while liquor reactor system of Klabin Paraná Papéis (Fig. 1). Mathematical models were developed for nine causticizing reactors using the same approach adopted by Andreola et al. (2007). The models were numerically resolved with the concepts of apparent and actual concentrations, and the simulation results were compared to each other and with the plant measurements of temperature, AA and TTA.

\section{MATERIALS AND METHODS}

\section{Mathematical Modeling}

The causticizing reactor system shown in Figure 1 is divided in two distinct parts: a slaker reactor and nine causticizing reactors. The causticizing reactors $\mathrm{C} 1$ to $\mathrm{C} 9$ were analyzed in this work in the same experiment in which the slaker reactor was previously modeled and simulated by Andreola et al. (2007).

The causticizing reactor mathematical model was obtained by component mass balances, according to Equations 1 to 7, and energy balance, Equation 9 , based on causticizing reactor $i$. It was considered a perfect mixture, constant volume, 
water loss by evaporation and variations in the volumetric flow of lime mud at the reactor outlet due to the production of carbonate and calcium hydroxide and the consumption of water and calcium oxide by the slaking and causticizing reactions.

$$
\begin{aligned}
& \frac{d C_{a, i}^{*}}{d t}=\frac{1}{V_{i}}\left(q_{i-1} C_{a, i-1}^{*}-q_{i} C_{a, i}^{*}\right)-r_{1}\left(\frac{M_{a}}{M_{\mathrm{Na}_{2} \mathrm{O}}}\right) \\
& \frac{d C_{b, i}^{*}}{d t}=\frac{1}{V_{i}}\left(q_{i-1} C_{b, i-1}^{*}-q_{i} C_{b, i}^{*}\right)+2 r_{1}\left(\frac{M_{b}}{M_{N a_{2} \mathrm{O}}}\right) \\
& \frac{d C_{c, i}^{*}}{d t}=\frac{1}{V_{i}}\left(q_{i-1} C_{c, i-1}^{*}-q_{i} C_{c, i}^{*}\right) \\
& \frac{d m_{d, i}}{d t}=\frac{m_{d, i-1}}{V_{i-1}} q_{i-1}-\frac{m_{d, i}}{V_{i}} q_{i}-V_{i} r_{2} \\
& \frac{d m_{e, i}}{d t}=\frac{m_{e, i-1}}{V_{i-1}} q_{i-1}-\frac{m_{e, i}}{V_{i}} q_{i}-V_{i}\left(\frac{M_{e}}{M_{N a_{2} O}}\right) r_{1}+ \\
& V_{i}\left(\frac{M_{e}}{M_{d}}\right) r_{2} \\
& \frac{d m_{f, i}}{d t}=\frac{m_{f, i-1}}{V_{i-1}} q_{i-1}-\frac{m_{f, i}}{V_{i}} q_{i}+V_{i}\left(\frac{M_{f}}{M_{\mathrm{Na} 2} \mathrm{O}}\right) r_{1} \\
& \frac{d m_{g, i}}{d t}=\frac{m_{g, i-1}}{V_{i-1}} q_{i-1}-\frac{m_{g, i}}{V_{i}} q_{i}
\end{aligned}
$$

where: $\mathrm{a}-\mathrm{Na}_{2} \mathrm{CO}_{3}$; b $-\mathrm{NaOH}, \mathrm{c}-\mathrm{Na}_{2} \mathrm{~S} ; \mathrm{d}-\mathrm{CaO}$ and $-\mathrm{Ca}(\mathrm{OH})_{2} ; \mathrm{f}-\mathrm{CaCO}_{3} ; \mathrm{g}-$ inert solids.

The supposition of a perfect mixture is grounded on the work by Hypponen and Luukko (1984), who demonstrated that the distribution of the residence time of solids was equal to that of the liquid in a causticizing reactor system. The balance of components $\mathrm{a}, \mathrm{b}$, and $\mathrm{c}$ was deduced in terms of apparent concentrations $\left(\mathrm{C}_{\mathrm{a}}{ }^{*}, \mathrm{C}_{\mathrm{b}}{ }^{*}, \mathrm{C}_{\mathrm{c}}{ }^{*}\right)$. These concentrations represent the mass of a given dissolved component per reactor volume unit (RVU). However, in strict sense, these concentrations do not represent their actual concentrations in the liquid phase of the reaction mixture, as part of the reactor volume is filled with solids. $\mathrm{CaCO}_{3}, \mathrm{CaO}, \mathrm{Ca}(\mathrm{OH})_{2}$, and inert solids from the lime added to the slaker reactor must have their volumes subtracted for evaluating the actual concentration of the component in the solution. In this way, the actual concentration of a generic component $\mathrm{i}\left(\mathrm{C}_{\mathrm{i}}\right)$ was determined from its apparent concentration $\left(\mathrm{C}_{\mathrm{i}}^{*}\right)$ using Equation 8.
$C_{i}=C_{i}^{*} \cdot\left(\frac{V_{i}}{V r}\right)$

where: $V r=V_{i}-\left(\frac{m_{f, i}}{\rho_{f}}+\frac{m_{e, i}}{\rho_{e}}+\frac{m_{d, i}}{\rho_{d}}+\frac{m_{g, i}}{\rho_{g}}\right)$

The operating temperatures of the first causticizing reactors are very close to the boiling point of the reaction mixture. Additionally, the reactions involved in the process are exothermal, which favors the increase of the medium temperature. In this way, the energy loss was computed by evaporation $\left(q_{\text {evap }}\right)$ in the energy balance in Equation 9 (for further details, see Andreola, 2001).

$$
\frac{d T_{i}}{d t}=C_{1}-q_{\text {evap }} C_{2}
$$

where:

$$
\begin{aligned}
C_{1}= & \frac{1}{V_{i} \rho_{\text {mud }} C p_{\text {mud }}}\left[\Delta H_{\text {mud }}+\Delta H_{\text {solid }}+\left(-\Delta H_{1}\right) V_{i} r_{1}\right. \\
& \left.+\left(-\Delta H_{2}\right) V_{i} r_{2}-U A_{i}\left(T_{i}-T_{\text {amb }}\right)\right] ; \\
C_{2}= & \frac{\rho_{\text {H2O }} \Delta H_{\text {evap }}}{V_{i} \rho_{\text {mud }} C p_{\text {mud }}}
\end{aligned}
$$

As the reactor temperature (T) was lower than the boiling temperature of the reaction mixture $\left(\mathrm{T}_{\mathrm{eb}}\right)$, evaporation was dismissed; therefore, $\mathrm{q}_{\mathrm{evap}}=0$. However, as soon as the reactor temperature reached $\mathrm{T}_{\mathrm{eb}}$, the water evaporated at constant temperature. The evaporation rate $\left(\mathrm{q}_{\text {evap }}\right)$ was evaluated instantaneously with the following equation: $\mathrm{C}_{1}-\mathrm{q}_{\mathrm{evap}} \mathrm{C}_{2}=0$.

As previously mentioned, the lime mud stream is basically formed by a sodium hydroxide aqueous solution with carbonate and calcium hydroxide, inert solids, and occasionally unreacted calcium oxide in suspension. Consequently, the lime mud volumetric flow inside reactor $\mathrm{i}\left(\mathrm{q}_{\mathrm{i}}\right)$ is constituted by the sum of five distinct components: water $\left(\mathrm{q}_{\mathrm{H} 2 \mathrm{O}}\right)$, calcium carbonate $\left(\mathrm{q}_{\mathrm{CaCO} 3}\right)$, calcium hydroxide $\left(\mathrm{q}_{\mathrm{Ca}(\mathrm{OH}) 2}\right)$, calcium oxide $\left(\mathrm{q}_{\mathrm{CaO}}\right)$, and inert solids ( $\left.\mathrm{q}_{\text {inert }}\right)$, as shown in Equation 10.

$$
q_{i}=q_{\mathrm{H} 2 \mathrm{O}, \mathrm{i}}+q_{\mathrm{CaCO} 3}+q_{\mathrm{Ca}(\mathrm{OH}) 2}+q_{\mathrm{CaO}}+q_{\text {inert }}
$$

where:

$$
q_{\mathrm{CaCO}_{3}}=q_{i}\left(\frac{m_{f, i}}{V_{i} \rho_{f}}\right) ; q_{\mathrm{Ca}(\mathrm{OH}) 2}=q_{i}\left(\frac{m_{e, i}}{V_{i} \rho_{e}}\right)
$$


$q_{\text {cao }}=q_{i}\left(\frac{m_{d, i}}{V_{i} \rho_{d}}\right) ; q_{\text {inert }}=q_{i}\left(\frac{m_{g, i}}{V_{i} \rho_{g}}\right)$

In turn, the volumetric flow rate of the water $\left(\mathrm{q}_{\mathrm{H} 2 \mathrm{O}}\right)$ could be calculated from its mass balance considering a pseudo stationary behavior, evidencing the water consumption in the slaking reaction $\left(\mathrm{q}_{\text {reaction }}\right)$ and loss by evaporation $\left(\mathrm{q}_{\text {evap }}\right)$, as given in Equation 11.

$q_{H 2 O, i}=q_{H 2 O, i-1}-q_{\text {reaction }}-q_{\text {evap }}$

where:

$$
q_{\text {reaction }}=\frac{r_{1} V_{i}}{\rho_{\mathrm{H}_{2} \mathrm{O}}}\left(\frac{M_{\mathrm{H}_{2} \mathrm{O}}}{M_{\mathrm{Na}_{2} \mathrm{O}}}\right)
$$

Combining Equations 10 and 11 gives the lime mud volumetric flow rate at the outlet of causticizing reactor $\mathrm{i}, \mathrm{q}_{\mathrm{i}}$, Equation 12.

$q_{i}=\left(\frac{V_{i}}{V r}\right)\left(q_{i-1}-q_{\text {racation }}-q_{\text {enap }}\right)$

The reaction rate equations for slaking $\left(\mathrm{r}_{2}\right), \mathrm{CaO}_{(\mathrm{s})}$ $+\mathrm{H}_{2} \mathrm{O}_{(\mathrm{l})} \rightarrow \mathrm{Ca}(\mathrm{OH})_{2(\mathrm{~s})}$, and causticizing $\left(\mathrm{r}_{1}\right)$, $\mathrm{Na}_{2} \mathrm{CO}_{3(\mathrm{aq})}+\mathrm{Ca}(\mathrm{OH})_{2(\mathrm{~s})} \rightarrow 2 \mathrm{NaOH}_{(\mathrm{aq})}+\mathrm{CaCO}_{3(\mathrm{~s})}$, employed in this work were those used by Swanda (1994), Equations 13 and 14, respectively.

$r_{2}=k_{2}\left(\frac{m_{d, i}}{V_{i}}\right)$

$r_{1}=\left(\frac{M_{N a 2 O}}{M_{a}}\right) C_{a, i-1}^{*}\left(\frac{m_{e, i}}{V_{i}}\right) A$

where:

$$
\begin{aligned}
& \mathrm{A}=\left\{k_{1} C_{a, i}^{*}\left(\frac{M_{\mathrm{Na} 2 O}}{M_{a}}\right)-k_{1^{\prime}}[E A]^{2}\right\} \\
& E A=C_{b, i}^{*} \frac{M_{\mathrm{Na}_{2} \mathrm{O}}}{M_{b}}+0,5 C_{c, i}^{*} \frac{M_{\mathrm{Na}_{2} \mathrm{O}}}{M_{c}}
\end{aligned}
$$

\section{Numerical Solution}

The mathematical model described above was numerically solved by integrating the differential equations system sequentially with subroutine SDRIV2, available at Kahaner et al. (1989), that is: causticizing reactor $1(\mathrm{C} 1)$ was simulated by admitting that initially it was in the same conditions as the slaker reactor in steady state conditions. Next, C2 was simulated by admitting that it was initially in the same conditions as those of $\mathrm{C} 1$ at steady state, and so forth until the last reactor (C9). It would be worth pointing out that the initial conditions of simulation of $\mathrm{C} 1$ were obtained from steady state values reported by Andreola et al. (2007) for the operation of the slaker reactor of the system depicted in Figure 1 operating in steady state.

\section{Evaluation of the Model Parameters}

The mathematical model has a thermal parameter, $\mathrm{U}$, and three apparent kinetic parameters: $\mathrm{k}_{2}, \mathrm{k}_{1,0}$, and $k_{2,0}$. The kinetic parameters used were those employed by Swanda (1994), while the global heat transfer coefficients of causticizing reactors $\mathrm{C} 1$ to C4 were estimated with Equation 15 (Lydersen, 1979), as described by Andreola (2007). The values of $\mathrm{U}$ were considered null for causticizing reactors $\mathrm{C} 5-\mathrm{C} 9$, as they were thermally isolated. All the parameter values used in the simulations are presented in Table 2.

$$
\frac{1}{U A}=\frac{1}{h_{e x t} A}+\frac{e}{A_{l m} k_{w}}+\frac{1}{h_{\text {int }} A}
$$

Table 2 - Thermal and Kinetic parameters.

\begin{tabular}{ccccc}
\hline Reactor & $\mathrm{U}(\mathrm{J} / \mathrm{K} \cdot \mathrm{m} . \mathrm{s})$ & $\mathrm{k}_{2}\left(\mathrm{~s}^{-1}\right)$ & ${ }^{*} \mathrm{k}_{1,0}(-)$ & ${ }^{* *} \mathrm{k}_{2,0}(-)$ \\
\hline C1 - C $~$ & 6.2790 & $5.5510^{-3}$ & 950.0 & 5.95 \\
C5 - C6 & 0.0 & $5.5510^{-3}$ & 950.0 & 5.95 \\
C7 - C & 0.0 & $5.5510^{-3}$ & 950.0 & 5.95 \\
\hline
\end{tabular}

\footnotetext{
$*_{k_{1}}=k_{1,0} \exp \left[-9.5 \times 10^{-2}(T T A-112.33)-27190 / R T\right]$

$*_{k_{1}}=k_{2,0} \exp \left[-6.04 \times 10^{-2}(T T A-112.33)-23004.14 / R T\right]$
}

\section{RESULTS AND DISCUSSION}

Figures 2 to 10 give the results of the simulations for SR and C1-C9 in steady state. The analysis of
Figures 2, 3, and 4 revealed that the simulations made based on the apparent concentration concept resulted in the values lower than those obtained using the actual concentration concept, which was 
due to the use of only the actual liquid volumes in the reactors in the calculations of the actual concentrations, while in the case of the apparent concentrations, the solid and liquid volumes were considered together, thus giving a lower value for the apparent concentration of the component.

In a similar way, both the active alkali values and the total titrable alkali obtained from the apparent concentrations were also lower than the values obtained from the actual steady state conditions, as seen in Figures 5 and 6. The comparison of the AA and TTA experimental measures, free of solids in suspension and in steady state, led to the conclusion that the actual concentration concept results were closer to the experimental values, indicating its preferential use.

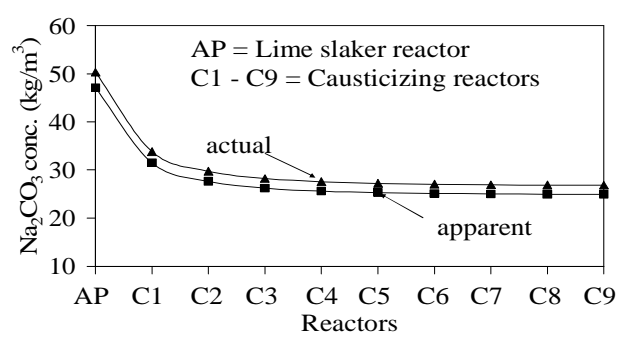

Figure $2-\mathrm{Na}_{2} \mathrm{CO}_{3}$ concentration in steady state across the reactors.

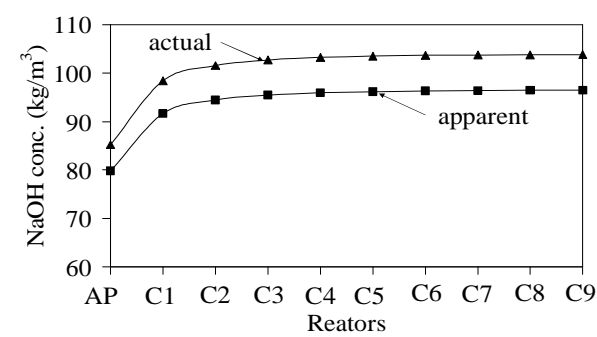

Figure 3 - $\mathrm{NaOH}$ concentration in steady state across the reactors.

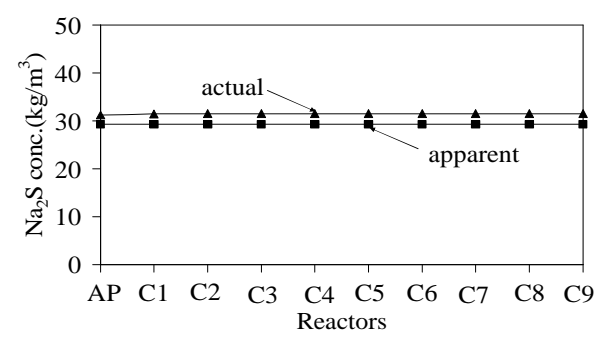

Figure $4-\mathrm{Na}_{2} \mathrm{~S}$ concentration in steady state across the reactors.

The fact that the active alkali increased up to $\mathrm{C} 2$ (Fig. 5) and stabilized from $\mathrm{C} 3$ on indicated that the causticizing reaction occurred more pronouncedly up to $\mathrm{C} 3$ without further significant effect in the subsequent reactors. A possible explanation for the nearly invariable TTA values in the causticizing reactors (Fig. 6), was that TTA consisted of the concentrations of components $\mathrm{Na}_{2} \mathrm{CO}_{3}, \mathrm{NaOH}$, and $\mathrm{Na}_{2} \mathrm{~S}$, relative to the same base $\left(\mathrm{Na}_{2} \mathrm{O}\right)$. Thus, the TTA value remained constant because an increase in the $\mathrm{NaOH}$ concentration resulted in a decrease in the $\mathrm{Na}_{2} \mathrm{CO}_{3}$ concentration due to the causticizing reaction, compensating each other, while the concentration of $\mathrm{Na}_{2} \mathrm{~S}$ remained constant (Fig. 4) as it did not participate in the slaking and causticizing reactions. 


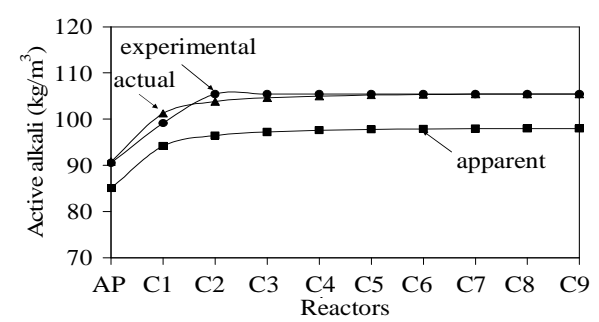

Figure 5 - Active alkali (AA) in steady state across the reactors.

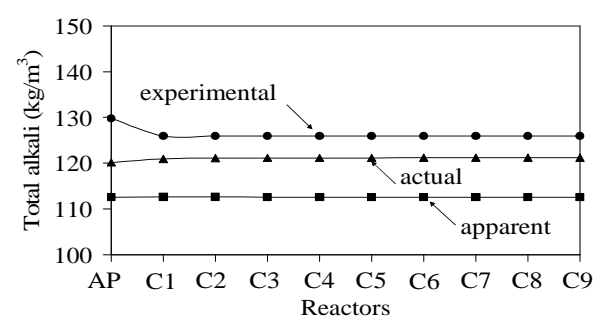

Figure 6 - Total alkali (AA) in steady state across the reactors.

The analysis of the mass simulations of $\mathrm{Ca}(\mathrm{OH})_{2}$ per RVU in steady state conditions given in Figure 7 showed a high consumption of $\mathrm{CaO}$ in the slaking reactions in $\mathrm{C} 1$ and that it tended to zero in C3. In turn, the mass of $\mathrm{Ca}(\mathrm{OH})_{2}$ per RVU also decreased across the causticizing reactors due to its increased consumption, in contrast to the total $\mathrm{CaO}$ mass, which slowly decreased in the first reactors and tended to a negligible value only after $\mathrm{C} 7$, showing that the causticizing reaction rate was much smaller than the slaking reaction rate.

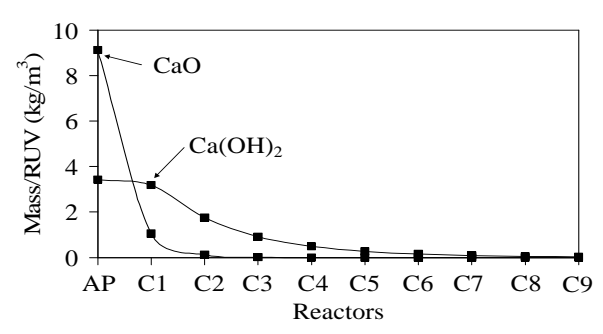

Figure $7-\mathrm{CaO}$ and $\mathrm{Ca}(\mathrm{OH})_{2}$ masses in steady state across the reactors.

Calcium hydroxide is produced in the slaking reaction from calcium oxide and consumed in the causticizing reaction, producing calcium carbonate, so that the $\mathrm{Ca}(\mathrm{OH})_{2}$ mass in the reactors at any instant results from the competition between these two reactions. Figure 7 showed that the $\mathrm{CaO}$ mass quickly decreased after the slaker reactor, tending to null close to $\mathrm{C} 3$, which indicated the end of the slaking reaction. In contrast, the $\mathrm{Ca}(\mathrm{OH})_{2}$ mass became null only around $\mathrm{C} 7$, characterizing a smaller reaction rate and the end of the causticizing reaction. It indicated that the reactor system analyzed was overdimensioned and that the last two reactors, $\mathrm{C} 8$ and $\mathrm{C} 9$, were redundant. This allows for an increase in the white liquor production without an expansion of the current reactor system.

The calcium carbonate mass increased significantly in the first three causticizing reactors and to a lesser extent in the subsequent reactors, as shown in Figure 8. In contrast, the inert solid mass remained constant across all the reactors, as it resulted from the inert solids in the lime added to the slaker reactor.

Similarly for AA and TTA, the mathematical model explained the thermal behavior of the system satisfactorily in steady state conditions. As observed in Figure 9, the largest difference between the simulation and the experimental values was in the order of $2{ }^{\circ} \mathrm{C}$ in $\mathrm{C}$. It could also 
be noted that the simulation temperature remained at $100{ }^{\circ} \mathrm{C}$ from $\mathrm{C} 1$ to $\mathrm{C} 3$, decreased to $99.6{ }^{\circ} \mathrm{C}$ in $\mathrm{C} 4$ and remaining nearly stable throughout to $\mathrm{C} 9$. The lime mud volumetric flow rate across the causticizing reactors $\left(\mathrm{q}_{\mathrm{i}}\right)$ was influenced mainly by the water $\left(\mathrm{q}_{\mathrm{H} 2 \mathrm{O}}\right)$ and secondarily by the calcium carbonate $\left(\mathrm{q}_{\mathrm{CaCO}}\right)$, and in negligible form by the calcium oxide and hydroxide $\left(\mathrm{q}_{\mathrm{CaO}}, \mathrm{q}_{\mathrm{Ca}(\mathrm{OH}) 2}\right)$ and inert solid ( $\mathrm{q}_{\text {Inert }}$ ), as shown in Figure 10. The difference between the total $\mathrm{q}_{\mathrm{i}}$ and $\mathrm{q}_{\mathrm{H} 2 \mathrm{O}}$ flow rates at the outlet of C9 was in the order of $7.10 \%$, almost entirely due to the production of calcium carbonate in the causticizing reaction.
Water is the main constituent of lime mud. However, the water content of this stream $\left(\mathrm{q}_{\mathrm{H} 2 \mathrm{O}}\right)$ can be affected by both the water consumption in the slaking reaction $\left(\mathrm{q}_{\mathrm{r} 1}\right)$ and by water loss by evaporation $\left(\mathrm{q}_{\text {evap }}\right)$, in agreement with Equation 11. The analysis of Figure 11 showed that water loss both by evaporation and in the slaking reaction was significant only in the slaker reactor, being negligible in the other reactors (C1-C9), which makes the difference between the water flow rate input $\left(\mathrm{q}_{\mathrm{H} 2 \mathrm{O}, \mathrm{i}-1}\right)$ and output $\left(\mathrm{q}_{\mathrm{H} 2 \mathrm{O}, \mathrm{i}}\right)$ of the causticizing reactors null.

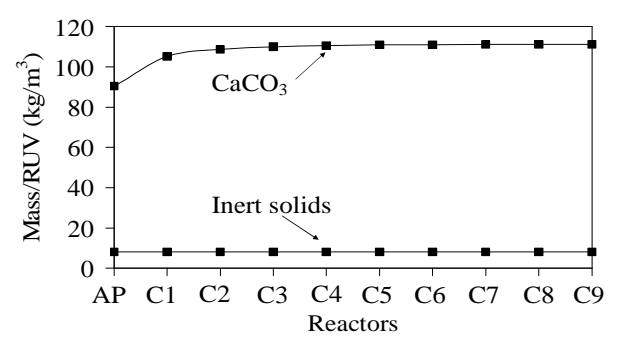

Figure $8-\mathrm{CaCO}_{3}$ and inert solid masses in steady state across the reactors.

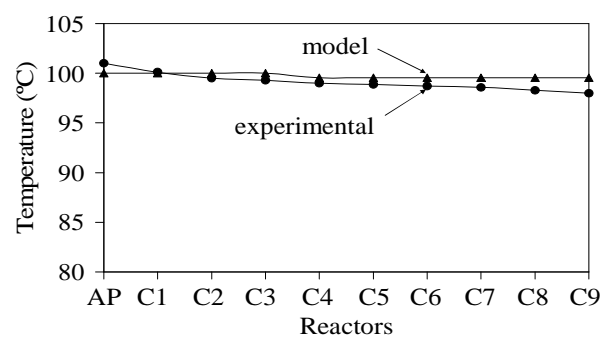

Figure 9 - Temperature in steady state across the reactors.

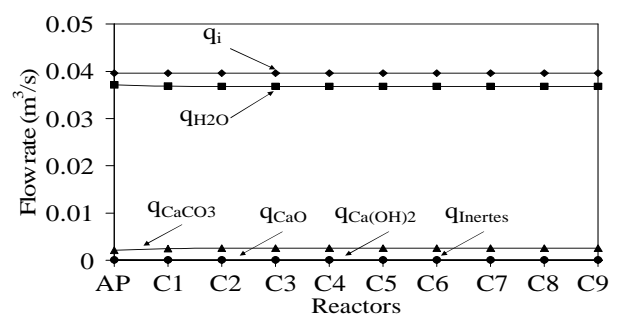

Figure 10 - Total lime mud flow, $\mathrm{q}_{\mathrm{i}}$, in steady state across the reactors.

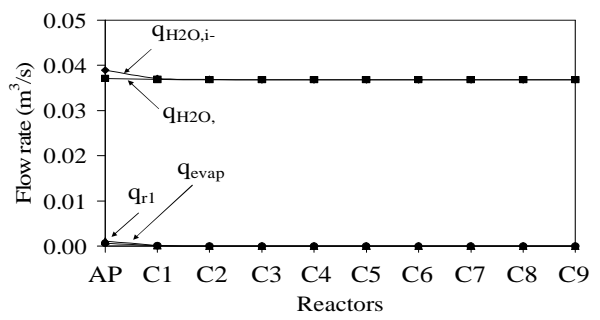

Figure 11 - Water flow rate, $\mathrm{q}_{\mathrm{H} 2 \mathrm{O}}$, in steady state across the reactors. 


\section{CONCLUSIONS}

- The developed model simulated the behavior of the industrial causticizing reactors in steady state satisfactorily, not requiring any parameter fitting.

- The use of the actual concentration concept was indicated for modeling the reactor system for the generation of white liquor.

- The difference between the actual and apparent concentrations of $\mathrm{Na}_{2} \mathrm{CO}_{3}, \mathrm{NaOH}$, and $\mathrm{Na}_{2} \mathrm{~S}$ was significant, with a mean value of $7.0 \%$.

- The causticizing reaction was much slower than the slaker reaction. In steady state conditions, the slaking reaction was nearly completed in C3, the fourth system reactor, while the causticizing reaction was completed in about the eighth reactor, $\mathrm{C} 7$.

- The difference between the lime mud and water flow rates at the causticizing reactor system outlet was about $7.1 \%$ and it resulted mainly from the calcium carbonate present in the lime mud suspension.

- In the operating conditions investigated, the reactor system analyzed was overdimensioned, making the last two reactors, $\mathrm{C} 8$ and $\mathrm{C} 9$ redundant, which allows for an increase in the white liquor production without an expansion of the current reactor system.

\section{NOMENCLATURE}

\begin{tabular}{|c|c|}
\hline A & area, $\mathrm{m}^{2}$ \\
\hline AA & active alkali, such as $\mathrm{Na}_{2} \mathrm{O}, \mathrm{kg} / \mathrm{m}^{3}$ \\
\hline $\mathrm{C}$ & concentration, $\mathrm{kg} / \mathrm{m}^{3}$ \\
\hline $\mathrm{Cp}$ & heat capacity, J/(kg.K) \\
\hline $\mathrm{E}$ & activation energy, $\mathrm{J} / \mathrm{gmol}$ \\
\hline $\mathrm{e}$ & reactor wall thickness, $\mathrm{m}$ \\
\hline EA & effective alkali, such as $\mathrm{Na}_{2} \mathrm{O}, \mathrm{kg} / \mathrm{m}^{3}$ \\
\hline $\mathrm{h}$ & heat transfer coefficient, $\mathrm{J} /\left(\right.$ K.s.m $\left.{ }^{2}\right)$ \\
\hline $\mathrm{H}$ & $\begin{array}{l}\text { causticizing reaction enthalpy, } \mathrm{J} / \mathrm{kg}_{\mathrm{Na} 2 \mathrm{O}} \\
\text { slaking reaction enthalpy, } \mathrm{J} / \mathrm{kg}_{\mathrm{CaO}}\end{array}$ \\
\hline $\mathrm{k}$ & $\begin{array}{l}\text { thermal conductivity, } \mathrm{J} /(\mathrm{s} \cdot \mathrm{m} . \mathrm{K}) \text {, or relative } \\
\text { to kinetic parameters }\end{array}$ \\
\hline $\mathrm{m}$ & mass, $\mathrm{kg}$ \\
\hline M & Molar mass $(\mathrm{kg} / \mathrm{mol})$ \\
\hline q & volumetric flow rate, $\mathrm{m}^{3} / \mathrm{s}$ \\
\hline $\mathrm{R}$ & ideal gas constant, $\mathrm{J} /(\mathrm{gmol} . \mathrm{K})$ \\
\hline $\mathrm{r}$ & $\begin{array}{l}\text { reaction speed, } \mathrm{kg}_{\mathrm{Na} 2 \mathrm{O}} /\left(\mathrm{m}^{3} . \mathrm{s}\right) \text { for the } \\
\text { causticizing reaction, and } \mathrm{kg}_{\mathrm{CaO}} /\left(\mathrm{m}^{3} . \mathrm{s}\right) \text { for } \\
\text { the slaking reaction }\end{array}$ \\
\hline
\end{tabular}

$\mathrm{T}$ temperature, ${ }^{\circ} \mathrm{C}$

TTA total titrable alkali, such as $\mathrm{Na}_{2} \mathrm{O}, \mathrm{kg} / \mathrm{m}^{3}$

U global heat transfer coefficient $\mathrm{J} /\left(\mathrm{K} . \mathrm{m}^{2} . \mathrm{s}\right)$

V Operating volume, $\mathrm{m}^{3}$

\section{Greek Symbols \\ $\Delta \quad$ variation \\ $\rho \quad$ fluid density, $\mathrm{lb} / \mathrm{ft}^{3}$ \\ $\tau \quad$ residence time, $\mathrm{s}$}

$\begin{array}{ll}\text { Subscripts } \\ \text { eb } & \text { boiling } \\ \text { evap } & \text { evaporation } \\ \text { ext } & \text { external } \\ \text { in } & \text { reactor inlet } \\ \text { int } & \text { internal } \\ \text { mud } & \text { liquor and lime mud suspension } \\ \mathrm{lm} & \text { logarithmic mean } \\ \mathrm{W} & \text { wall } \\ \text { i } & \text { relative to the reactor number } \\ 1 & \text { relative to the causticizing reaction } \\ 2 & \text { relative to the slaking reaction }\end{array}$

\section{ACKNOWLEDGMENTS}

The authors thank the technical and financial support from Universidade Estadual de Maringá and Klabin Paraná Papéis.

\section{REFERENCES}

Aguiar, H. C.; Maciel Filho, R. (2001), Neuronal network and hybrid model: a discussion about different modeling techniques to predict pulping degree with industrial data. Chem. Eng. Sci., 56, 565570.

Andrade, A. A.; Sartori, C. R. F.; Costa, V. L.; Freitas, M.; Rothen, T.; d'Angelo (2009), Implementation of advanced control and optimization in the causticizing process. O Papel, 70, 11, 66-77.

Andreola, R.; Vieira, O.; Santos, O. A. A.; Jorge, L. M. M. (2007), Effect of Water Losses by Evaporation and Chemical Reaction in an Industrial Slaker Reactor. Braz. Arch. Biol. Techn., 50 (2), 339-347.

Andreola, R. (2001), Modeling, Simulation and Analysis of Klabin Paraná Papéis Causticizing Reactor System. M.S. Thesis (in Portuguese), State University of Maringá, Maringá, Brazil.

Barber, V. A., Scott, G. M. (2007), Dynamic modeling of a paper machine, part I: programming and software development. Tappi J., 6 (1), 11-17. 
BRACELPA - Associação Brasileira de Celulose e Papel (2009a). Desempenho do setor e projeções. <www.bracelpa.org.br/bra/estatisticas/pdf/booklet/ booklet.pdf $>$, (acessed 10.02.10).

BRACELPA - Associação Brasileira de Celulose e Papel (2009b). Relatório Anual 2008/2009. <www.bracelpa.org.br/bra/estatisticas/pdf/rel2008. pdf $>$, (acessed 10.02.10).

Costa, A. O. S.; Biscaia Jr., E. C.; Lima, E. L. (2004), Mathematical description of the kraft recovery boiler furnace. Comput. Chem. Eng., 28, 633-641.

Gonçalves, E. C.; Silva, C. M.; Alves, L. J. L.; Gomide, J. L.; Carneiro, C. J. G. (2008), Sodium metaborate autocausticizing for eucalyptus kraft-antraquinone pulp production. $O$ Papel, 4, 42-50.

Holman, K. L.; Warrick, R. P.; Carlson, K. R. (1991), Recausticizing kinetics with mill liquor and lime. AIChE Forest Products Symposium Proceedings, AIChE, NewYork, 23-31.

Hypponen, O. and Luuko A. (1984), The residence time distributions of liquor and lime mud flows in the recausticizing process. Tappi J., 67 (7), 46-48.

Kahaner, D. Moler, C. Nash, S. (1989), Numerical methods and software. Prentice Hall Series in Computational Mathematics, New Jersey.

Kovac, S.; Gough, B.; Le, L.; Roberts, G. (1999), A new generation of adaptative model based predictive controllers applied in batch reactor. Control Eng., 2331.

Lopes, R.; Fleet, V. R.; Figueiredo, D. (2008), Multivariable process control applications for the pulp industry. O Papel, 69 (11), 75-86.

Lydersen, L. A. (1979), Fluid flow and heat transfer. John Wiley and Sons, New York.

Malberg, B., Edwards, L. (2007), Dynamic modeling of pressurized peroxide stages with application to full bleach plant simulation. Tappi J., 6 (2), 9-17.
Medeiros, R. G.; Silva Jr., F. G.; Báo, S. N.; Hanada, R.; Ferreira Filho, E. X. (2007), Application of Xylanases from Amazon Forest Fungal Species in Blenching of Eucalyptus Kraft Pulps. Braz. Arch. Biol. Techn., 50 (2), 231-238.

Sethuraman, J.; Krishnagopalan, J.; Krishnagopalan, G. (1995), Kinetic model for the causticizing reaction. Tappi J., 78 (1), 115-120.

Silva, F. A.; Restrepo, A.; Rodrigues, L. A.; Gedraite, R. (2008), Variability reduction and efficiency increase in lime kilns using advanced process control. O Papel, 69 (12), 75-85.

Soares, N. S.; Silva, M. L.; Lima, J. E.. (2007), A função de produção da indústria brasileira de celulose, em 2004. Rev. Árvore, 31 (3), 495-502.

Swanda, A. P.; Seborg, D. E.; Holman, K. L.; Sweerus, N. (1997), Dynamic models of the causticizing process. Tappi J., 80 (12), 123-134.

Swanda, A. P. (1994), Process modeling and control system evaluation for the pulp and paper recausticizing process. M.S. Thesis, University of California, USA.

Uronen, P.; Aurasmaa, H. (1979), Modelling and simulation of causticization plant and lime kiln. Pulp Pap-Canada, 80 (6), 162-165.

Vilkari, L.; Kantelinen, A.; Linko, M. (1994), Xylanases in blanching: from and idea to industry. FEMS Microbiol. Rev., 13, 335-355.

Zeng, L., van Heiningen, A. R. P., A Mathematic Model for Direct Causticization of $\mathrm{Na} 2 \mathrm{CO} 3$ with TiO2 in a Semi-batch Reactor. Can. J. Chem. Eng., 80, 948-953, 2002. 